\title{
Kepatuhan Kunjungan Antenatal Care pada Ibu Hamil di Puskesmas Muara Batu Kabupaten Aceh Utara
}

\author{
Silmiyanti ${ }^{1}$, Idawati ${ }^{2}$ \\ Mahasiswa Gizi Kesehatan Keluarga Kespro S2 IKM Institut Kesehatan Helvetia, Medan \\ STIKes Medika Nurul Islam Sigli \\ Email : Najwa.f4r4@gmail.com \\ Email : idawati.medika@gmail.com \\ DOI : $10.32672 /$ jsa.v7i5.1524
}

\begin{abstract}
Antenatal care (ANC) is a comprehensive and quality antenatal care provided to all pregnant women. The initial survey conducted at the North Aceh District Muara Batu Health Center found that K1 coverage in 2016 was $90 \%$ and K4 coverage was $79 \%$, this had not yet reached the set target of $100 \%$. The aim of the study was to determine the effect of knowledge, attitudes, availability of ANC services, access to health services, husband's support and sources of information on adherence to conducting antenatal care visits at Muara Batu health center in North Aceh Regency in 2018. Mixed method research with quantitative and qualitative approaches. The population is all pregnant women who visited when the researchers conducted the study, namely as many as 32 respondents. The quantitative approach sample is 32 respondents with total sampling technique. The qualitative sample consisted of 3 pregnant women, 3 husbands and 1 midwife. The results showed that there was a relationship of compliance visits to do antenatal care with knowledge, attitudes and sources of information on pregnant women. It is recommended for pregnant women to increase their knowledge about antenatal care visits through electronic media and print media, besides that they are expected to attend if there is an extension meeting or posyandu in the village that delivers health information specifically about antenatal care.
\end{abstract}

Keywoards : Compliance, ANC visit, Pregnant

\begin{abstract}
ABSTRAK
Antenatal care (ANC) adalah pelayanan antenatal komprehensif dan berkualitas yang diberikan kepada semua ibu hamil. Survei awal yang dilakukan di Puskesmas Muara Batu Kabupaten Aceh Utara didapatkan bahwa cakupan K1 pada tahun 2016 yaitu sebesar $90 \%$ dan cakupan K4 yaitu sebesar $79 \%$, hal ini belum mencapai target yang ditetapkan yaitu $100 \%$. Tujuan penelitian untuk mengetahui pengaruh pengetahuan, sikap, ketersediaan pelayanan ANC, akses pelayanan kesehatan, dukungan suami dan sumber informasi terhadap kepatuhan melakukan kunjungan antenatal care di puskesmas Muara Batu Kabupaten Aceh Utara tahun 2018. Jenis penelitian mixed method dengan pendekatan kuantitatif dan kualitatif. Populasi adalah semua ibu hamil yang melakukan kunjungan saat peneliti melakukan penelitian, yaitu sebanyak 32 responden. Sampel pendekatan kuantitatif sebanyak
\end{abstract}


32 responden dengan tehnik pengambilan sampel total sampling. Sampel kualitatif terdiri dari 3 orang ibu hamil, 3 orang suami dan 1 orang bidan. Hasil penelitian menunjukkan bahwa ada hubungan kunjungan kepatuhan melakukan antenatal care dengan pengetahuan, sikap dan sumber informasi pada ibu hamil. Disarankan kepada ibu hamil untuk menambah pengetahuan tentanGkunjungan antenatal care melalui media elektronik maupun media cetak, selain itu diharapkan menghadiri bila ada pertemuan penyuluhan ataupun posyandu di desa yang menyampaikan informasi kesehatan khususnya tentang antenatal care.

Kata kunci : Kepatuhan, antenatal care, Ibu hamil

\section{PENDAHULUAN}

Indikator keberhasilan pembangunan kesehatan dapat dilihat dari peningkatan atau penurunan derajat kesehatan. Salah satu indikator derajat kesehatan tersebut adalah Angka Kematian Ibu (AKI). Persoalan kematian yang terjadi disebabkan oleh pendarahan, eklamsi, aborsi, dan infeksi. Selain masalah medis, tingginya kematian ibu juga karena pemberdayaan perempuan yang kurang baik, latar belakang pendidikan perempuan, masalah ketidaksetaraan gender, nilai budaya, perekonomian serta rendahnya perhatian laki-laki terhadap ibu hamil dan melahirkan. Oleh karena itu, pandangan yang menganggap kehamilan adalah peristiwa alamiah perlu diubah secara sosiokultural. Sangat diperlukan upaya peningkatan pelayanan perawatan ibu hamil baik oleh pemerintah, swasta, maupun masyarakat terutama suami. (Harahap \& Siregar, 2014)

Sejak tahun 1990 upaya strategis yang dilakukan dalam upaya menekan Angka Kematian Ibu (AKI) adalah dengan pendekatan safe motherhood, dengan menganggap bahwa setiap kehamilan mengandung risiko, walaupun kondisi kesehatan ibu sebelum dan selama kehamilan dalam keadaan baik.(Sari \& Efendi, 2017) Di Indonesia Safe Motherhood Initiative ditindaklanjuti dengan peluncuran Gerakan Sayang Ibu di tahun 1996 oleh Presiden yang melibatkan berbagi sektor pemerintahan di samping sektor kesehatan. Salah satu program utama yang ditujukan untuk mengatasi masalah kematian ibu adalah penempatan bidan di tingkat desa secara besar -besaran yang bertujuan untuk mendekatkan akses pelayanan kesehatan ibu dan bayi baru lahir ke masyarakat. Di tahun 2000, Kementerian Kesehatan RI memperkuat strategi intervensi sektor kesehatan untuk mengatasi kematian ibu dengan mencanangkan strategi Making Pregnancy Safer. Pada tahun 2012 Kementerian Kesehatan meluncurkan program Expanding Maternal and Neonatal Survival (EMAS) dalam rangka menurunkan angka kematian ibu dan neonatal sebesar 25\%. (Sari \& Efendi, 2017)

Angka kematian ibu di dunia masih tinggi, terutama di negara-negara berkembang. Setiap hari sekitar 800 perempuan meninggal akibat komplikasi kehamilan atau persalinan di dunia. Secara global pada tahun 2014, diperkirakan ada 289.000 kematian ibu selama dan setelah kehamilan. Di Indonesia, Angka Kematian Ibu (AKI) masih tinggi. Angka kematian ini berkaitan dengan kehamilan, persalinan, dan nifas. Bukan karena sebab lain. Berdasarkan Survei Demografi dan Kesehatan Indonesia (SDKI) tahun 2012, AKI sebesar 359 per 100.000 kelahiran hidup. Sementara target AKI di tahun 2015 adalah 102 kematian per 100.000 kelahiran hidup. Jadi, target angka ini masih jauh dari yang harus 
dicapai. Angka kematian ibu di Indonesia pada tahun 2015 yaitu sebanyak 305 ibu dan Hasil Survei Penduduk Antar Sensus (SUPAS) 2015 menunjukkan AKB sebesar 22,23 per 1.000 kelahiran hidup, yang artinya sudah mencapai target MDG 2015 sebesar 23 per 1.000 kelahiran hidup. (Zulfitria D., Yuniar, \& Irma Yunawati, 2017)

Tujuan dari Millennium Development Goals (MDG's) yaitu menurunkan angka kematian bayi menjadi 23 per 1000 kelahiran hidup dan target MDGs sekarang meningkatkan kesehatan ibu untuk menurunkan AKI menjadi 102 per 100.000 kelahiran hidup. Tujuan tersebut dapat dicapai dengan pemanfaatan pelayanan ANC bagi ibu hamil. Pelayanan ANC merupakan pemeriksaan pada ibu hamil selama masa kehamilannya untuk mencegah terjadinya komplikasi dan mempersiapkan kelahiran yang sehat. (Zulfitria D. et al., 2017)

Pelayanan kesehatan ibu dan anak meliputi antenatal care yang di laksanakan sejak kehamilan sampai post partum. Untuk antenatal care yang menjadi indikator adalah kunjungan pertama ibu hamil pada trimester pertama dan kunjungan keempat ibu hamil pada trimester III, yang dilakukan pada tempat pelayanan kesehatan. Asuhan antenatal ini di berikan untuk mendapatkan kondisi yang sehat bagi ibu maupun bayinya dengan cara membina hubungan saling percaya dengan ibu, mendeteksi komplikasi-komplikasi yang dapat mengancam jiwa, mempersiapkan kelahiran dan memberikan pendidikan atau pengetahuan sehubungan dengan kehamilannya. Ibu hamil dapat juga mengetahui pertumbuhan dan perkembangan bayinya sedini mungkin dan memahami perubahanperubahan yang dialaminya. Antenatal care (ANC) penting untuk menjamin agar proses alamiah tetap berjalan normal selama kehamilan, sebab setiap saat kehamilan ini dapat berkembang menjadi masalah atau komplikasi. Pemeriksaan kehamilan dapat di lakukan melalui Dokter Spesialis Obsgyn atau Bidan dengan minimal pemeriksaan 4 kali selama masa kehamilan. (Fahmi.A.Lihu, J.M.L.Umboh, \& G.d.Kandou, 2015)

Capaian pelayanan kesehatan ibu dapat dinilai menggunakan indikator cakupan K1 dan K4. Cakupan K1 adalah jumlah ibu hamil yang telah memperoleh pelayanan antenatal pertama kali, dibandingkan jumlah sasaran ibu hamil di wilayah kerja dalam kurun waktu satu tahun. Cakupan K4 adalah jumlah ibu hamil yang telah memperoleh pelayanan antenatal sesuai dengan standar, paling sedikit empat kali sesuai jadwal yang dianjurkan, dibandingkan jumlah sasaran ibu hamil di wilayah kerja dalam kurun waktu satu tahun. (Risza Choirunissa \& Syaputri, 2018)

Pada tahun 2016, cakupan pelayanan kesehatan ibu hamil K4 telah memenuhi target Rencana Strategis (Renstra) Kementerian Kesehatan sebesar 74\%. Namun demikian, terdapat 9 provinsi yang belum mencapai target tersebut yaitu Maluku Utara, Papua, Nusa Tenggara Timur, Papua Barat, Jambi, Maluku, Sulawesi Barat, Sulawesi Tenggara, dan DI Yogyakarta. Salah satu provinsi yang memiliki cakupan K4 terendah ke 10 di Indonesia pada tahun 2016 yaitu provinsi Aceh dengan cakupan K4 hanya sebesar 78,34\%. (Kementrian Kesehatan, 2017) Selain itu, berdasarkan data yang diperoleh dari Profil Kesehatan Aceh tahun 2016 didapatkan cakupan Indikator pelayanan Kesehatan Ibu dan Anak di Aceh Utara cakupan K1 tahun 2016 sebesar 79\% dan cakupan K4 sebesar 83,7\%. Beberapa hal yang mempengaruhi cakupan pelayanan antenatal yaitu kelengkapan sarana puskesmas, tenaga kesehatan serta pengetahuan dan sikap ibu hamil. (Dinas Kesehatan Aceh Tahun 2017, 2017) 
Peran seorang ibu hamil pada program pemeriksaan antenatal care sangatlah penting. Karenanya suatu pemahaman tentang program ini amat diperlukan untuk kalangan tersebut. Pemahaman ibu atau pengetahuan ibu terhadap antenatal care sangat dipengaruhi oleh tingkat pendidikan ibu, semakin tinggi tingkat pendidikan atau pengetahuan seseorang maka semakin membutuhkan pusat-pusat pelayanan kesehatan sebagai tempat berobat bagi dirinya dan keluarganya. Dengan berpendidikan tinggi, maka wawasan pengetahuan semakin bertambah dan semakin menyadari bahwa begitu penting kesehatan bagi kehidupan sehingga termotivasi untuk melakukan kunjungan ke pusatpusat pelayanan kesehatan yang lebih baik. (Ritonga \& Asiah, 2012)

Kunjungan ANC oleh ibu hamil dipengaruhi oleh beberapa faktor. Pembagian faktor yang memengaruhi perilaku seseorang dalam memanfaatkan pelayanan kesehatan berdasarkan teori Lawrence Green (1984), yaitu berasal dari faktor perilaku (behavior cause) dan faktor di luar perilaku (non-behavior causes). Sedangkan dalam pembagian menurut konsep dan perilaku sesorang seperti yang dikemukakan oleh Green meliputi faktor predisposisi (predisposing factor), faktor pemungkin (enabling factor), dan faktor penguat (reinforcing factor). Faktor predisposisi meliputi usia, pendidikan, pekerjaan, paritas, pengetahuan, dan sikap. Faktor pemungkin meliputi jarak tempat tinggal, penghasilan keluarga dan media informasi. Faktor penguat meliputi dukungan suami dan keluarga, serta dari petugas kesehatan yang ada. (Rachmawati, Puspitasari, \& Cania, 2017)

Perilaku ibu hamil yang tidak melakukan pemeriksaan kehamilan akan menurunkan cakupan ANC terutama K4, serta dapat berisiko meningkatkan AKI (Kemenkes RI, 2013). Hal ini didukung dengan hasil penelitian Ekowati (2009), menyatakan bahwa ibu yang tidak pernah atau kurang dari empat kali memeriksakan kehamilaan (ANC) mempunyai resiko kematian ibu 3,5 kali dari pada ibu yang memeriksakan kehamilan lebih dari empat kali. Berdasarkan hasil penelitian Cholifah (2015), terdapat hubungan faktor pendidikan, tingkat pengetahuan, sikap, dan persepsi dengan kunjungan K4 ibu hamil. Menurut Lisa Indrian Dini (2012) terdapat hubungan factor tingkat pendidikan, sikap, kepercayaan, status ekonomi, dukungan keluarga, dan akses terhadap pelayanan kesehatan dengan Pemanfaatan Pelayanan ANC Oleh Ibu Hamil. (Risza Choirunissa \& Syaputri, 2018)

Berdasarkan latar belakang, penulis tertarik untuk melakukan penelitian tentang analisis mixeds methods faktor-faktor yang memengaruhi kunjungan Antenatal care Ibu Hamil di Puskesmas Muara Batu Kabupaten Aceh Utara Tahun 2018.

\section{METODE}

Desain penelitian ini menggunakan metode campuran (mix methods) kuantitatif dan kualitatif. Pada penelitian kuantitatif menggunakan penelitian observasional analitik dengan rancangan potong lintang (cross sectional), dimana peneliti hanya melihat frekuensi dan karakter serta faktor paparan yang diamati oleh peneliti pada suatu populasi di saat tertentu. Pendekatan kuantitatif dilakukan dengan wawancara kepada responden bertujuan untuk menganalisis bagaimana faktor yang berhubungan terhadap kunjungan antenatal care pada ibu hamil. Pendekatan kualitatif dilakukan dengan indepth interview menggunakan pedoman wawancara yang bertujuan menggali lebih dalam bagaimana faktor yang berhubungan terhadap kunjungan antenatal care pada ibu hamil. (16) 
Silmiyanti, Idawati

Pengumpulan data kuantitatif dilakukan dengan pengisian lembar checklist dengan studi dokumentasi berupa data deskriptif, sedangkan Pengumpulan data kuantitatif dilakukan dengan mewawancarai secara mendalam kepada informan yang mewakili pasien dengan menggunakan pedoman wawancara. Kegiatan wawancara tersebut direkam menggunakan alat perekam. (16)

Analisa data kuantitatif diantaranya digunakan analisis univariat yang merupakan analisis menitikberatkan pada penggambaran atau deskripsi data yang telah diperoleh dan analisis bivariat adanya hubungan yang signifikan antara variabel bebas dengan variabel terikat digunakan analisis Chi-square, pada batas kemaknaan perhitungan statistik $\mathrm{p}$ value $(0,05)$. Apabila hasil perhitungan menunjukkan nilai $p<p$ value $(0,05)$. Sedangkan analisa data kualitatif menggunakan Triangulasi yang merupakan perbandingan informasi dari informan yang satu dengan informan yang lain sehingga informasi yang diperoleh kebenarannya. Selanjutnya melakukan keabsahan data.

\section{HASIL PENELITIAN KUANTITATIF}

Dari hasil penelitian yang dilakukan oleh penulis mengenai "analisis mixed methods faktor-faktor yang memengaruhi kepatuhan melakukan kunjungan antenatal care pada ibu hamil di puskesmas muara batu kabupaten aceh utara tahun 2018", maka diperoleh karakteristik responden sebagai berikut :

\section{Analisis Univariat}

Berdasarkan tabel diatas dapat dilihat bahwa distribusi frekuensi pengetahuan ibu hamil di Puskesmas Muara Batu yang berpengetahuan baik 12 orang (37,5\%), berpengetahuan kurang 20 orang $(62,5 \%)$. Distribusi frekuensi sikap ibu hamil di Puskesmas Muara Batu yang bersikap positif 15 orang (46,9\%), bersikap negatif 17 orang $(53,1 \%)$, distribusi frekuensi ketersediaan pelayanan Antenatal care di puskesmas Muara Batu Kabupaten Aceh Utara yang baik 11 orang $(34,4 \%)$ dan ketersediaan pelayanan Antenatal care yang kurang 21 orang $(65,6 \%)$. distribusi frekuensi akses pelayanan kesehatan di puskesmas Muara Batu Kabupaten Aceh Utara yang mudah 11 orang $(34,4 \%)$ dan ketersediaan pelayanan Antenatal care yang Akses sulit 21 orang $(65,6 \%)$. Distribusi frekuensi ibu hamil yang mendapatkan dukungan suami adalah 13 orang $(40,6 \%)$ dan yang tidak mendapatkan dukungan suami 19 orang $(59,4 \%)$, distribusi frekuensi ibu hamil yang mendapatkan informasi 18 orang $(56,3 \%)$ dan yang tidak mendapatkan informasi 18 orang (56,3\%), distribusi frekuensi ibu hamil yang tidak patuh melakukan kunjungan Antenatal care 18 orang (56,3\%) dan ibu hamil yang patuh melakukan kunjungan Antenatal care 14 orang (43,8\%).

\section{Analisis Bivariat}

Berdasarkan analisis data diketahui bahwa 32 responden yang memiliki pengetahuan baik 12 orang (100\%) dengan kunjungan antenatal care tidak patuh 12 orang (100\%) dan tidak ada kunjungan antenatal care yang patuh sedangkan pengetahuan kurang 20 orang $(100 \%)$ dengan kunjungan antenatal care tidak patuh 6 orang $(30 \%)$ dan kunjungan antenatal care yang patuh 14 orang $(70 \%)$. 
Selanjutnya dari hasil analisa chi-square pada lampiran tabel uji chi-square antara hubungan pengetahuan ibu hamil dengan kunjungan antenatal care, diketahui bahwa nilai probabilitasnya $0,000<\operatorname{sig} \_\alpha=0,05$. Hasil analisis ini memenuhi kriteria persyaratan hipotesis ada hubungan, sehingga dapat disimpulkan bahwa pengetahuan ibu hamil mempunyai hubungan yang signifikan terhadap kunjungan antenatal care.

Pada variabel sikap dari 32 responden yang memiliki sikap positif 15 orang $(100 \%)$ dengan kunjungan antenatal care tidak patuh 15 orang (100\%) dan tidak kunjungan antenatal care yang patuh sedangkan sikap negatif 17 orang (100\%) dengan kunjungan antenatal care tidak patuh 3 orang $(17,6 \%)$ dan kunjungan antenatal care yang patuh 14 orang $(82,4 \%)$. Selanjutnya dari hasil analisa chi-square pada lampiran tabel uji chi-square antara hubungan sikap ibu hamil dengan kunjungan antenatal care, diketahui bahwa nilai probabilitasnya $0,000<\operatorname{sig} \_\alpha=0,05$. Hasil analisis ini memenuhi kriteria persyaratan hipotesis ada hubungan, sehingga dapat disimpulkan bahwa sikap ibu hamil mempunyai hubungan yang signifikan terhadap kunjungan antenatal care.

Pada variabel Ketersedian pelayanan Antenatal care dari dari 32 responden yang terdapat ketersedian pelayanan antenatal care yang kurang yaitu 21 orang (100\%) dengan kunjungan antenatal care tidak patuh 13 orang $(61,9 \%)$ dan kunjungan antenatal care yang patuh 8 orang $(38,1 \%)$, sedangkan ketersedian pelayanan antenatal care yang baik yaitu 11 orang (100\%) dengan kunjungan antenatal care tidak patuh 5 orang $(45,5 \%)$ dan kunjungan antenatal care yang patuh 6 orang $(54,5 \%)$. Selanjutnya dari hasil analisa chisquare pada lampiran tabel uji chi-square antara hubungan ketersedian pelayanan antenatal care dengan kunjungan antenatal care, diketahui bahwa nilai probabilitasnya $\left(0,373>\operatorname{sig} \_\alpha=0,05\right.$. Hasil analisis ini memenuhi kriteria persyaratan hipotesis tidak ada hubungan, sehingga dapat disimpulkan bahwa ketersedian pelayanan antenatal care tidak mempunyai hubungan yang signifikan terhadap kunjungan antenatal care.

Pada variabel akses kesehatan yaitu 21 orang (100\%) dengan kunjungan antenatal care tidak patuh 13 orang $(61,9 \%)$ dan kunjungan antenatal care yang ti patuh 8 orang $(38,1 \%)$, sedangkan mudahnya akses pelayanan kesehatan yaitu 11 orang (100\%) dengan kunjungan antenatal care tifdak patuh 5 orang $(45,5 \%)$ dan kunjungan antenatal care yang patuh 6 orang $(54,5 \%)$. Selanjutnya dari hasil analisa chi-square pada lampiran tabel uji chi-square antara hubungan akses pelayanan kesehatan dengan kunjungan antenatal care, diketahui bahwa nilai probabilitasnya $(0,373>\operatorname{sig} \alpha=0,05$. Hasil analisis ini memenuhi kriteria persyaratan hipotesis tidak ada hubungan, sehingga dapat disimpulkan bahwa akses pelayanan kesehatan tidak mempunyai hubungan yang signifikan terhadap kunjungan antenatal care.

Pada variabel dukungan suami dari 32 responden yang tidak mempunyai dukungan suami yaitu 19 orang (100\%) dengan kunjungan antenatal care tidak patuh 11 orang $(57,9 \%)$ dan kunjungan antenatal care yang patuh 8 orang $(42,1 \%)$, sedangkan yang mempunyai dukungan suami yaitu 13 orang (100\%) dengan kunjungan antenatal care tidak patuh 7 orang $(53,8 \%)$ dan kunjungan antenatal care yang patuh 6 orang $(46,2 \%)$.Selanjutnya dari hasil analisa chi-square pada lampiran tabel uji chi-square antara hubungan dukungan suami dengan kunjungan antenatal care, diketahui bahwa nilai probabilitasnya $(0,821>\operatorname{sig} \alpha \alpha=0,05$. Hasil analisis ini memenuhi kriteria persyaratan 
Silmiyanti, Idawati

hipotesis tidak ada hubungan, sehingga dapat disimpulkan bahwa dukungan suami tidak mempunyai hubungan yang signifikan terhadap kunjungan antenatal care.

Pada variabel sumber informasi dari 32 responden, ibu hamil yang tidak mendapatkan informasi 18 orang $(100 \%)$ dengan kunjungan antenatal care tidak patuh 18 orang $(100 \%)$ dan tidak ada kunjungan antenatal care yang patuh sedangkan ibu hamil yang mendapatkan informasi 14 orang (100\%) dengan tidak ada kunjungan antenatal care yang tidak patuh dan kunjungan antenatal care patuh 14 orang $(100 \%)$. Selanjutnya dari hasil analisa chi-square pada lampiran tabel uji chi-square antara hubungan sumber informasi dengan kunjungan antenatal care, diketahui bahwa nilai probabilitasnya $(0,000<$ $\operatorname{sig} \alpha=0,05$. Hasil analisis ini memenuhi kriteria persyaratan hipotesis ada hubungan, sehingga dapat disimpulkan bahwa dukungan suami mempunyai hubungan yang signifikan terhadap kunjungan antenatal care.

\section{Hasil Penelitian Kualitatif}

Berdasarkan wawancara secara mendalam kepada informan ibu hamil dapat disimpulkan bahwa tidak seluruh informan mengetahui apa yang dimaksud dari kunjungan Antenatal care . Dari jawaban informan A yang mendekati benar definisi dari kunjungan Antenatal care .

Hasil wawancara secara mendalam kepada informan suami dapat disimpulkan bahwa seluruh informan kurang mengetahui apa yang dimaksud dari kunjungan Antenatal care . Dari jawaban informan B yang mendekati benar definisi dari kunjungan Antenatal care .

Berdasarkan wawancara secara mendalam kepada informan bidandapat disimpulkan bahwa informan mengetahui apa yang dimaksud dari kunjungan Antenatal Care.

\section{PEMBAHASAN}

Antenatal care merupakan cara penting untuk memonitoring dan mendukung kesehatan ibu hamil normal dan mendeteksi ibu dengan kehamilan normal, ibu hamil sebaiknya dianjurkan untuk mengunjungi bidan atau dokter sedini mungkin semenjak ia merasa dirinya hamil untuk mendapatkan pelayanan dan asuhan antenatal. (Wulandari, 2016)

Pemeriksaan atau pengawasan antenatal memberikan manfaat dengan ditemukannya berbagai kelainan yang menyertai kehamilan secara dini. Sehingga dapat diperhitungkan dan dipersiapkan langkah-langkah dalam pertolongan persalinannya. Manfaat antenatal care sangat besar karena dapat mengetahui berbagai resiko dan komplikasi kehamilan sehingga ibu hamil dapat diarahkan untuk melakukan rujukan. Manfaat asuhan antenatal untuk ibu adalah mengurangi dan menegakkan secara dini komplikasi kehamilan, mempertahankan dan meningkatkan kesehatan mental dan fisik ibu hamil untuk menghadapi persalinan, meningkatkan kesehatan ibu setelah persalinan dan untuk memberikan ASI. Konseling dalam pemakaian alat kontrasepsi KB, memberikan nasehat dan petunjuk berbagai masalah yang berkaitan dengan kehamilannya serta berusaha menetapkan penggolongan kehamilan dengan faktor resiko atau resiko tinggi akan menentukan pertolongan persalinan yang aman. (Murniati, 2007). Hal ini sejalan dengan penelitian Niken yang menyatakan bahwa "Setiap ibu hamil wajib melakukan 
antenatal care untuk mengetahui perkembangan janinnya. Ibu hamil disarankan untuk meningkatkan kesadaran pentingnya pemeriksaan antenatal care . (Febyanti \& Susilawati, 2012)

Pelayanan kesehatan ibu selama kehamilan merupakan hal penting bagi ibu hamil maupun bayi yang dikandungnya. Upaya pelayanan tersebut merupakan salah satu upaya pencegahan terhadap kondisi buruk yang dapat terjadi pada seorang ibu hamil. Berbagai kondisi dapat terjadi pada seorang ibu hamil. Adapun kondisi paling buruk yang dapat terjadi pada seorang ibu hamil adalah kematian. Jika standar pelayanan dilaksanakan sudah sesuai dengan prosedur diharapkan dapat mendeteksi risiko tinggi pada ibu hamil lebih awal dan dapat dilakukan rujukan sesegera mungkin. (Marlisman, 2017)

Hasil tersebut di atas sejalan dengan pendapat Notoatmodjo (2003) bahwa aspek pengetahuan merupakan domain yang sangat penting untuk terbentuknya perilaku seseorang, semakin tinggi tingkat pengetahuan seseorang akan dapat mempengaruhi pola pikir dan sikap terhadap sesuatu hal yang akhirnya akan mempengaruhi terjadinya perubahan perilaku. (Trisnawati, 2012)

Menurut asumsi peneliti mayoritas pengetahuan ibu kurang karena ibu merasa bahwa pengetahuan itu hanya didapat dijenjang pendidikan saja. Pada kenyataannya pengetahuan tidak hanya didapatkan dari jenjang pendidikan saja, bisa dari melihat seperti menonton $\mathrm{TV}$, membaca dan mendengar informasi-informasi yang diberikan oleh tenaga kesehatan. Oleh karena itu, untuk meningkatkan pengetahuan responden yang kurang diharapkan dapat menambah pengetahuan tentang kunjungan Antenatal care melalui media elektronik maupun media cetak dan mengikuti pertemuan penyuluhan ataupun posyandu di desa .

Antenatal care merupakan pengawasan sebelum persalinan terutama ditentukan pada pertumbuhan dan perkembangan janin dalam rahim. Tujuan Antenatal care yaitu memantau kemajuan kehamilan untuk memastikan kesehatan ibu dan tumbuh kembang janin. pemeriksaan antenatal dilaksanakan sesuai jadwal berdasar kebijakan departemen kesehatan.

Kunjungan Antenatal care ibu hamil dipengaruhi oleh beberapa factor yaitu faktor predisposisi (predisposing factor), faktor pemungkin (enabling factor) dan faktor penguat (reinforcing factor).

Faktor predisposisi yang memengaruhi kepatuhan ibu hamil dalam melakukan kunjungan Antenatal care mencakup hal-hal sebagai berikut: a) usia memengaruhi pola pikir seseorang. Ibu dengan usia produktif (20-35 tahun) dapat berfikir lebih rasional dibandingkan dengan ibu dengan usia yang lebih muda atau terlalu tua. Sehingga ibu dengan usia produktif memiliki motivasi lebih dalam memeriksakan kehamilannya. b). Tingkat pendidikan seseorang menentukan seberapa besar pengetahuan yang dimilikinya. Ibu hamil yang berpendidikan memiliki pemahaman yang lebih mengenai masalah kesehatan sehingga memengaruhi sikap mereka terhadap kehamilannya sendiri maupun pemenuhan gizinya selama hamil. Faktor pemungkin mencakup ketersediaan sarana dan prasarana atau fasilitas kesehatan bagi masyarakat seperti, rumah sakit, poliklinik, posyandu, dokter atau bidan praktik swasta. Faktor pemungkin yang memengaruhi kepatuhan ibu hamil dalam melakukan kunjungan Antenatal care mencakup hal-hal 
berikut: a). jarak tempat tinggal, semakin jauh jarak fasilitas kesehatan dari tempat tinggal ibu hamil serta semakin sulit akses menuju ke fasilitas kesehatan akan menurunkan motivasi ibu hamil untuk melakukan kunjungan antenatal care.

Jika mayoritas Ketersediaan pelayanan Antenatal care kurang maka, responden tidak memanfaatkan ketersedian pelayanan Antenatal care dengan baik karena kurangnya pengetahuan. Selain itu, faktor geografis (jarak, waktu tempuh, dan sarana transportasi) terhadap ketersediaan pelaynan Antenatal care merupakan komponen pendukung yang menyebabkan masyarakat menggunakan pelayanan kesehatan. Akses pelayanan kesehatan sulit akan mengurangi pemanfaatan pelayanan kesehatan yang merupakan hasil dan proses pencarian pelayanan kesehatan oleh seseorang maupun kelompok. Begitu juga dengan suami tidak mendukung maka Ibu hamil tidak dapat menjalani masa kehamilanya dengan baik.

Suami adalah salah satu kunci agar ibu bisa memelihara emosi positif pada masa kehamilan. Saat ngidam, istri cenderung manja dan menjadi lebih sensitif. Suami dituntut untuk memiliki kematangan emosi yang lebih baik agar dapat menghadapi perubahan emosional ibu selama periode kehamilan. Calon ayah harus bisa menghadapi "periode manja" dan "periode tidak nyaman" yang terjadi pada ibu selama masa kehamilan dengan penuh kesabaran. Sikap positif dan dukungan yang baik dari suami akan membuat proses kehamilan berjalan menyenangkan dan kondisi janin pun selalu sehat dan kuat.

Dampak dari ibu yang tidak sesuai melakukan pemeriksaan sesuai anjuran bidan, maka resiko tidak dapat dideteksi secara dini dan rujukan pun terlambat dilakukan, sehingga ibu dan bayi tidak dapat ditangani secara maksimal. Apabila keluarga tidak mendukung dengan penuh kehamilan, dikhawatirkan ibu tidak dapat beradaptasi dengan baik mengenai ketidaknyamanan kehamilan. Untuk mengurangi resiko pada kehamilan yang disebabkan kurangnya dukungan keluarga maka setidaknya tercipta komunikasi yang baik khususnya dengan pasangan, keluarga, teman. Komunikasi atau hubungan emosional yang baik akan membantu menghadapi kesulitan dan kesedihan (Dalam, Pemeriksaan, \& Care, 2012).

Jika ibu hamil mendapatkan informasi maka ibu hamil dapat memeriksa kehamilan secara teratur dan diharapkan dapat mendeteksi lebih dini risiko kehamilan atau persalinan, baik bagi ibu maupun janin. Karena penyulit kehamilan baru mempunyai arti pada triwulan terakhir dan bertambah besar kemungkinan terjadinya menjelang akhir kehamilan, maka pemeriksaan setelah bulan ke-6 harus diperketat. Selain dari itu timbang berat badan setiap kali periksa hamil, minum satu tablet tambah darah setiap hari selama hamil, imunisasi TT, dan mendapat penyuluhan dari petuga kesehatan. Dengan adanya kunjungan yang teratur dan pengawasan yang rutin dari bidan atau dokter, maka selama masa kunjungan tersebut diharapkan komplikasi yang mungkin terjadi selama hamil dapati kenali secara lebih dini dan dapat ditangani dengan cepat dan tepat. Hal ini dapat mengurangi risiko kesakitan dan kematian bagi ibu hamil. Untuk itu peran bidan sebagai ujung tombak pelayanan harus mampu dan terampil dalam memberikan pelayanan sesuai dengan standart yang ditetapkan. Peran bidan antara lain meningkatkan cakupan kunjungan pertama ibu hamil (K1), dan kunjungan keempat ibu hamil (K4). 
Serambi Akademica

Jurnal Pendidikan, Sains, dan Humaniora
Vol. 7, No. 5,

Oktober 2019
pISSN 2337-8085

eISSN 2657- 0998

\section{KESIMPULAN}

Berdasarkan hasil penelitian yang telah dilakukan tentang tentang analisis mixeds methods faktor-faktor yang memengaruhi kepatuhan melakukan kunjungan Antenatal Care pada ibu hamil di Puskesmas Muara Batu Kabupaten Aceh Utara Tahun 2018 ada hubungan kunjungan Antenatal care dengan pengetahuan, sikap dan sumber informasi pada ibu hamil, serta tidak ada hubungan dengan ketersediaan pelayanan ANC, akses pelayanan kesehatan dan dukungan suami pada ibu hamil.

\section{UCAPAN TERIMA KASIH}

Pada kesempatan ini, saya mengucapkan terima kasih kepada pihak puskesmas Muara Batu telah memberikan izin tempat dilakukannya penelitian ini

\section{DAFTAR PUSTAKA}

Dinas Kesehatan Aceh Tahun 2017. (2017). Profil Kesehatan Aceh Tahun 2016 (pp. 1160).

Fahmi.A.Lihu, J.M.L.Umboh, \& G.d.Kandou. (2015). Analisis Hubungan Antara Faktor Internal dan Faktor Eksternal Ibu Hamil Dalam Melakukan Tindakan Antenatal Care Di Puskesmas Global Limboto Kabupaten Gorontalo. JIKMU, 5, 427-435.

Febyanti, N. K., \& Susilawati, D. (2012). Hubungan Pengetahuan Ibu Hamil Tentang Antenatal Care Terhadap Perilaku Kunjungan Kehamilan. Jurnal Keperawatan Soedirman, 7, 148-157. https://doi.org/http://dx.doi.org/10.20884/1.jks.2013.8.2.470

Harahap, R., \& Siregar, M. (2014). Pengaruh Karakteristik Ibu dan Dukungan Suami Terhadap Pemeriksaan Kehamilan di Kecamatan Angkola Timur Kabupaten Tapanuli Selatan. Jurnal Ilmiah PANNMED, 8, 317-325.

Kementrian Kesehatan. (2017). Profil Kesehatan Indonesia Tahun 2016. https://doi.org/10.1111/evo.12990

Marlisman, D. P. (2017). Gambaran Mutu Pelayanan Antenatal Care Di Puskesmas Ciputat Timur Tahun 2017.

Murniati. (2007). Faktor-Faktor Yang Berhubungan Dengan Pemanfaatan Pelayanan Antenatal oleh Ibu Hamil di Kabupaten Aceh Tenggara.

Rachmawati, A. I., Puspitasari, R. D., \& Cania, E. (2017). Faktor-faktor yang Memengaruhi Kunjungan Antenatal Care ( ANC ) Ibu Hamil. Majority, 7, 72-76. https://doi.org/10.1002/2013WR015233

Risza Choirunissa, \& Syaputri, N. D. (2018). Analisis Faktor Yang Berhubungan Dengan Pemeriksaan K4 Pada Ibu Hamil Di Puskesmas Bakung Provinsi Lampung Tahun 2017. Jurnal Akademi Keperawatan Husada Karya Jaya, 4, 72-93.

Ritonga, F. J., \& Asiah, N. (2012). Faktor-Faktor Yang Mempengaruhi Ibu Hamil Dalam Melakukan Pemeriksaan Antenatal Care. Jurnal Kesehatan, 1-5.

Sari, K. I. P., \& Efendi, H. V. (2017). Analisis Faktor Yang Berpengaruh Terhadap Kunjungan Antenatal Care. Jurnal Keperawatan Dan Kebidanan, 9, 93-113.

Trisnawati, R. (2012). Hubungan Pengetahuan Dan Informasi Ibu Hamil Tentang Kehamilan Resiko Tinggi Dengan Kepatuhan Kunjungan Antenatal Care Di 
Silmiyanti, Idawati

Puskesmas Kuta Baro. Jurnal Ilmiah, 1-9.

Wulandari, S. E. (2016). Faktor - Faktor Yang Berhubungan Dengan Pemeriksaan Antenatal Care Kunjungan Pertama (K1) Pada Ibu Hamil Di Wilayah Kerja Puskesmas Pisangan Kota Tangerang Selatan.

Zulfitria D., Yuniar, N., \& Irma Yunawati. (2017). Faktor yang Berhubungan Dengan Pemanfaatan Pelayanan Antenatal Care pada Ibu Hamil Di Wilayah Kerja Puskesmas Mawasangka Tengah Kabupaten Buton Tengah Tahun 2017, 2, 1-10. 